\title{
The History of The Remains of The Roman Emperor, Julian the Apostate
}

$\int$ ulian (Flavius Claudius Iulianus), known as the Apostate, the Roman Emperor between 361-363, was one of the most intriguing rulers. He has inspired a great deal of interest among generations of researchers ${ }^{1}$. He was both a just emperor, a skilled administrator, a wise commander, and a talented writer.

The literary work of Julian the Apostate is vast although it cannot be fully assessed because some of the emperor's works have been lost. The ruler left behind numerous literary pieces ${ }^{2}: 8$ orations; 2 satires - Misopogon, or the Beard Hater, and The Caesars, a polemic treatise Against the Galilaeans; a collection of

\footnotetext{
${ }^{1}$ G. Negri, L’imperatore Giuliano Apostata, Milano 1901; J. Bidez, La vie de l'Empereur Julien, Paris 1930; R. Braun, J. Richer, L'empereur Julien. De l'histoire à la légende, Paris 1978; G. Ricciotti, L'imperatore Giuliano l'Apostata secondo i documenti, Verona 1962; G.W. Bowersock, Julian the Apostate, London 1978; R. Browning, The Emperor Julian, Los Angeles 1978; P. Athanassiadi, Julian. An Intellectual Biography, London-New York 1992; IDEM, Giuliano. Ultimo degli imperatori pagani, Genova 1994; R. Smith, Julian's Gods. Religion and Philosophy in the Thought and Action of Apostate, London-New York 1995; W. CERAn, Kościót wobec antychrześcijańskiej polityki cesarza Juliana Apostaty, Łódź 1980 (= AUL.FH 1); S. OlszanieC, Julian Apostata jako reformator religijny, Kraków 1999; L. Bielas, Apostazja cesarza Juliana w świadectwach antycznych pisarzy i w nowożytnej historiografii, Kraków 2002; K. BRIngmann, Kaiser Julian. Der letzte heidnische Herrscher, Darmstadt 2004; K. Rosen, Julian. Kaiser, Gott und Christenhasser, Stuttgart 2006; T. SzeląG, Kampanie galijskie Juliana Apostaty. Argentoratum 357, Zabrze 2007; L. Jerphagnon, Julien dit l'Apostat, Paris 2008; P. Ramos, La veritable histoire de Julien, Paris 2012; H.C. Teitler, The Last Pagan Emperor. Julian the Apostate and the War against Christianity, Oxford 2017; M. SPInelli, Giuliano l'Apostata. Anticristo o cercatore di dio?, Roma 2017; A. Marcone, Giuliano, Roma 2018.

${ }^{2}$ The Works of the Emperor Julian, vol. I-III, trans. W.C. WRIGHT, London-Cambridge Mass. 1962-1969 [=LCL, 13; 29; 157]; Julian ApostaTA, Listy, trans. W. Klinger, Wrocław 1962 [= BPLA, 9]; Cesarz Juljan Apostata i jego satyra Symposion, trans. L. ĆWIKLIŃski, Poznań 1936; Julian Apostata, List do rady $i$ ludu ateńskiego, trans. A. Pająkowska, Poznań 2006 [= FHA, 7]; Julian Apostata, Misopogon, czyli Nieprzyjaciel brody, trans. A. Pająkowska, Poznań 2009 [= FHA, 13]; Julian Apostata, List do filozofa Temistiosa, trans. A. PająKowska, Poznań 2011 [= FHA, 22]; Julian Apostata, Przeciw Galilejczykom, trans. A. PająKowska, Poznań 2012 [= FHA, 24]; Julian Apostata, Cesarze, trans. A. Pająkowska, Poznań 2013 [= FHA, 27].
} 
87 letters; and extensive official correspondence 3 . However, it should be clearly stated that his correspondence is decisively more valuable as documents of the epoch than literary pieces. Many a researcher has evaluated his literary activity critically, claiming that while it reflects the emperor's stormy and unusual life, it is marked by superficiality rather than in-depth analysis". Despite their deficiencies and imperfections, Julian's letters provide a wealth of valuable information about him and his reign as well as the Roman Empire in the second half of the fourth century. Moreover, they are an excellent supplement to other sources, both Christian and Pagan.

Undoubtedly, Julian the Apostate was also one of the most educated Roman rulers.

\section{The death of the emperor Julian the Apostate}

It was a great desire of the emperor Julian the Apostate to defeat Persia, a Roman nemesis, and win back the lands that had been lost in the previous Roman-Persian wars 5 . He acted on this dream, however, his expedition to Persia resulted in the defeat of the Roman army and his death on June $26^{\text {th }}, 363$.

Julian the Apostate died under mysterious circumstances. His death and the events preceding it were depicted and interpreted in different ways, even by the participants of this tragic quest. These obscurities have triggered a lively polemic, which started in Julian's epoch and continue until this day. A number of works and articles examining the circumstances of the death of this exceptional emperor have been published ${ }^{6}$.

The historian Ammianus Marcellinus, an almost direct witness of the event, left a most interesting account of the wounding and the final hours of the emperor

\footnotetext{
${ }^{3}$ The Theodosian Code and Novels and the Sirmondian Constitutions, trans. et ed. C. Pharr, praef. C. Dickerman Williams, Princeton 1952.

${ }^{4}$ J. Wolski, Julian Apostata. Życie i twórczość, [in:] Julian Apostata, Listy..., p. VII.

${ }^{5}$ For more on the battles by the Roman-Persian border between 299-363, see: T. Szeląg, Amida 359, Warszawa 2012; A. DrabiK, Ktezyfont 363, Warszawa 2016; T. SińczaK, Wojny Cesarstwa Rzymskiego z Iranem Sasanidów w latach 226-363, Oświęcim 2016; J.S. HarreL, Wojna o Nisibis. Obrona rzymskiej wschodniej granicy 337-363, trans. A. PARADZIŃski, Oświęcim 2019; K. FARrokH, K. Maksymiuk, J.S. Gracia, The Siege of Amida (359 CE), Siedlce 2018.

${ }^{6}$ D. Conduché, Ammien Marcellin et la mort de Julien, L 24, 1965, p. 359-380; I. HaHN, Der ideologische Kampf um den Tod Julians des Abtrünnigen, K 38, 1960, p. 225-232; R.T. RidLEY, Notes on Julian's Persian Expedition (363), Hi 22, 2, 1973, p. 317-330; C.W. ForNARA, Julian's Persian Expedition in Ammianus and Zosimus, JHS 111, 1991, p. 1-15; J. KuRANC, Zgon cesarza Juliana Apostaty w świetle relacji współczesnych pisarzy pogańskich, RHu 14, 1966, p. 73-86; M. JACZYNowsKA, Imitatio Alexandri. Pare uwag na temat perskiej wyprawy cesarza Juliana, AUNC.H 29, 1996, p. 133-148; A. Раја̨коwsкa, Historyk Ammianus Marcellinus o śmierci cesarza Juliana Apostaty, StCN 7, 2005, p. 9-21; D. Woods, Gregory of Nazianzus on the Death of Julian the Apostate (Or. 5.13), Mn 68, 2015, p. 297-303.
} 
Julian the Apostate ${ }^{7}$. Marcellinus' description stands out from the testimonies of other authors, both non-Christian and Christian: Libanius', Zosimus', Gregory's of Nazianzus, Eutropius', Socrates Scholasticus', Sozomenus', Philostorgius', or Zonaras's. Julian the Apostate perished at the age of thirty-two. His independent reign lasted only twenty months: from November 361 to June 363.

The mystery surrounding the circumstances of the emperor's death extends to his remains. The burial site of the emperor Julian's body has been the subject of numerous reflections, starting from the Antiquity all the way to the present day ${ }^{9}$.

\section{Julian's burial in Tarsus}

After the Persian quest, the emperor had planned to stay for longer in Tarsus in Cilicia. Ammianus Marcellinus confirms this fact: [Julian] for he said that he had arranged when the campaign was finished to return by a shorter route to Tarsus in Cilicia for the purpose of wintering, and that he had written to Memorius, the governor of that city, to prepare everything that was necessary for his use ${ }^{10}$. The historian adds: And his not long afterwards came to pass; for his body was brought back there, and he was buried in a suburb of the city with simple rites, as he himself had directed ${ }^{11}$. Naturally, it does mean that the emperor wished to be buried in Tarsus with humili pompa. Julian hoped to return alive from the quest. He made all the necessary arrangements for his stay in Tarsus. Ammian confirms this unfortunate course of events: the emperor returned to Tarsus, as planned, but he was dead. Glanville Downey, on the other hand, believes that Julian made the wish to be

\footnotetext{
${ }^{7}$ Ammianus Marcellinus, Res gestae, XXV, 3 - ed.: Ammianus Marcellinus, vol. I-III, trans. J.C. Rolfe, London 1950-1952 [= LCL, 300] (cetera: Ammianus MarCellinus).

${ }^{8}$ Libanius, Orationes, XVIII - ed.: Libanius, Selected Works, vol. I, The Julianic Orations, ed. et trans. A.F. Norman, London-Cambridge Mass. 1987 [= LCL, 451] (cetera: Libanius); Zosime, Histoire nouvelle, III, 29, ed. et trans. F. PASCHOUd, vol. I-III, Paris 1979-2000 (cetera: Zosimos); Gregorius NaZIAnensis, Oratio, V, 18, [in:] PG, vol. XXXV; Ioannis Zonarae Epitome historiarum libri XIIIXVIII, III, 215, rec. T. Büttner-Wobst, Bonnae 1897 (cetera: Zonaras); Philostorgius, Kirchengeschichte, VII, 15, ed. J. Bidez, F. Winkelmann, Berlin 1981 [= GCS]; Eutropii Breviarium ab Urbe condita, X, 16, 2, ed. C. Santini, Leipzig 1979; Sokrates, Kirchengeschichte, III, 21, ed. G.C. HaNSEN, Berlin 1995 [= GCS.NF, 1] (cetera: Socrates Scholasticus); Sozomenus, Kirchengeschichte, VI, 1, ed. J. Bidez, G.C. Hansen, Berlin 1995 [= GCS.NF, 4] (cetera: Sozomenus).

${ }^{9}$ M. Di MaIo, The Transfer of the Remains of the Emperor Julian from Tarsus to Constantinople, B 48, 1978, p. 43-50; J. ArCE, La tumba del Emperador Juliano, Luc 3, 1984, p. 181-191; D. Woods, On the Alleged Reburial of Julian the Apostate in Constantinople, B 76, 2006, p. 364-371; G. DowneY, The Tombs of the Byzantine Emperors at the Church of the Holy Apostles in Constantinople, JHS 79, 1959, p. 27-51; M.J. Johnson, Observations on the Burial of the Emperor Julian in Constantinople, B 77, 2008, p. 254-260; A.A. VAsIliev, Imperial Porphyry Sarcophagi in Constantinople, DOP 4, 1948, p. 1-26; P. Grierson, C. MAngo, I. ŠEvČEnKo, The Tombs and Obits of the Byzantine Emperors (337-1042), DOP 16, 1962, p. 1-63.

${ }^{10}$ Ammianus Marcellinus, XXIII, 2, 5, vol. II, p. 317.

${ }^{11}$ Ammianus Marcellinus, XXIII, 2, 5, vol. II, p. 317.
} 
buried in Tarsus, should he perish, and to ensure that the burial ceremonies be modest. This complies with the lifestyle of Julian the Apostate ${ }^{12}$. Ammianus also notes that Julian's relative, Procopius was entrusted with escorting the emperor's body: Then Procopius was sent with the remains of Julian, in order to inter him, as he had directed when still alive, in the suburb of Tarsus ${ }^{13}$.

The ruler was therefore buried in the suburb of Tarsus by the road leading to the passes of Mount Taurus, in a mausoleum next to a small temple on the bank of the River Cydnus. He was laid to rest across from the grave of emperor Maximinus Daia.

Libanius observes that it ought more properly to have been in the Academy next to Plato's tomb so that he too might receive the honors paid to Plato by each successive generation of students and teachers ${ }^{14}$. Hence, the rhetorician believes that Julian's ashes, as expected from a true philosopher, should have been buried at the Plato's Academy in Athens. However, the historian Ammianus Marcellinus, suggests the following:

But his remains and ashes, if anyone then showed sound judgment, ought not to be looked on by the Cydnus, although it is a beautiful and clear stream, but to perpetuate the glory of his noble deeds they should be laved by the Tiber, which cuts through the eternal city and flows by the memorials of the deified emperors of old ${ }^{15}$.

The Father of the Church, Gregory of Nazianzus, recalls the fifteen-day journey of the emperor's body from Persia to Tarsus with contumely:

But as for the other, the circumstances attending his departure to the war were disgraceful (for he was pursued by mobs and townsfolk with vulgar and ribald cries, as most people yet remember), but still more inglorious was his return. What was his disgrace? Buffoons and mimes escorted him, the train moved along amidst foul jokes from the stage, with piping and dancing, whilst he was upbraided with his apostasy, his defeat, and his end, suffering every sort of insult, hearing every sort of thing in which such people indulge who make ribaldry their trade, until the city of Tarsus received him (why and wherefore condemned to this indignity I know not); where he has a consecrated ground without honor, a tomb accursed, a temple abominable, and not even to be looked at by pious eyes! ${ }^{16}$

Gregory thus emphasizes that Julian's remains were either welcomed with mournful lamentations or clamorous invectives. The Father of the Church wonders why the city of Tarsus was punished with such utter disgrace of becoming the resting place of this apostate.

${ }^{12} \mathrm{G}$. Downey, The Tombs..., p. 46.

${ }^{13}$ Ammianus Marcellinus, XXV, 9, 12, vol. II, p. 555.

${ }^{14}$ Libanius, Orationes, XVIII, 306, p. 486.

${ }^{15}$ Ammianus Marcellinus, XXV, 10, 5, vol. II, p. 557, 559.

${ }^{16}$ Gregorius Nazianzenus, Orationes, V, 18; trans.: http://www.tertullian.org/fathers/gregory_ nazianzen_3_oration5.htm [13 IX 2019]. 
A brief account on the transfer of Julian's body can also be found in Zosimus' New History. The author recalls that Jovian - Julian's successor - with his personal imperial guard set out to Antioch whereas the main part of the army accompanied Julian's body to Tarsus ${ }^{17}$. It is unlikely that the entire army headed to Tarsus. Most probably, Ammianus is right in saying that Julian's body was escorted by Procopius ${ }^{18}$, surely with a unit of the army. Zosimus comments on the emperor's remains as follows: Julian's body, which was taken to Cilicia and buried in a royal tomb in a suburb of Tarsus. And this inscription was written on the tomb: 'Having left the swift-flowing Tigris, Julian lies here, both a noble king and a valiant spearman'19.

In his Extracts of History (Epitome Historiarum) ${ }^{20}$, John Zonaras, a $12^{\text {th }}$-century historian, offers a great deal of interesting information. He confirms that it was the army that escorted Julian's body to Tarsus and that the emperor was buried near the city. Most likely, both Zonaras and Zosimus drew from the same source - Universal History by Eunapius of Sardis - of which only excerpts remain. At the end, Zonaras mentions, without giving a specific date, that Julian's body was transferred to Constantinople. All these historians agree on the burial site of Julian's body in Tarsus. It is noteworthy that the location of the sepulcher in the suburb of the city, that is pomerio itineris, was customary. Ammianus mentions

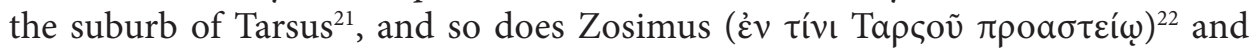

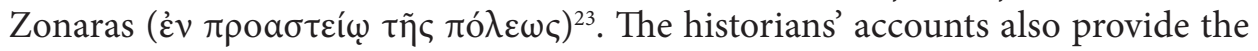
information that several months later, emperor Jovian, a Christian, arranged the tomb ornamentation (exornari sepulchrum) ${ }^{24}$ of his predecessor, a Pagan ruler, who - as some would argue - did not deserve such a privilege. Ammianus comments: [Jovian] though in excessive haste to leave that place, he determined to adorn the tomb of Julian, situated just outside the walls on the road which leads to the passes of Mount Taurus ${ }^{25}$.

\section{Epigram from Tarsus}

Both Zosimus and Zonaras reveal that there was an inscription on Julian's tomb in Tarsus. The historians provide its content:

\footnotetext{
${ }_{17}$ Zosimos, III, 43, 3.

${ }^{18}$ Ammianus Marcellinus, XXV, 9, 12.

${ }^{19}$ Zosimos, III, 34, 4; trans. - Zosimus, New History, trans. R.T. Ridley, Canberra 1982 [= BA, 2], p. 68.

${ }^{20}$ Zonaras, XIII, 13.

${ }^{21}$ Ammianus Marcellinus, XXIII, 2, 5; cf. XXV, 9, 12 (in suburbano Tarsensi); XXV, 10, 5 (in pomerio itineris).

${ }^{22}$ Zosimos, III, 34, 4.

${ }^{23}$ Zonaras, XIII, 13.

${ }^{24}$ Ammianus Marcellinus, XXV, 10, 5.

${ }^{25}$ Ammianus Marcellinus, XXV, 10, 5, vol. II, p. 557.
} 
Zosimus:

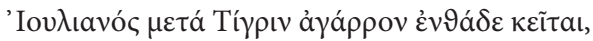

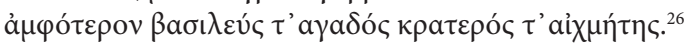

Zonaras:

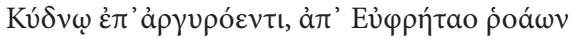

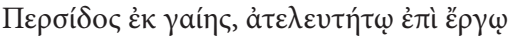

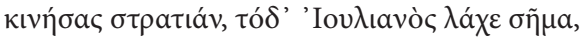

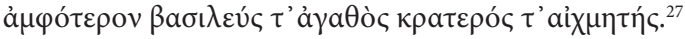

Both inscriptions thus offer two versions of the same text. Zosimus' epigram can also be found in the Palatine Anthology but it was ascribed to the rhetorician Libanius ${ }^{28}$. The last verse is a nod towards Homer, Julian's favorite poet $^{29}$. The Homeric tone of this epitaph agrees with the emperor's preference and suggests that it could have been written by one of the emperor's close friends: perhaps the ruler's personal physician, Oribasius. Eunapius borrowed it from Oribasius and Zosimus repeated $\mathrm{it}^{30}$.

Zonaras' epigram also comes from Eunapius, however, the chronicler offers an extended version of the epitaph, which is also cited by the Byzantine historian George Kedrenos in Historiarum Compendium ${ }^{31}$. It is noteworthy that Zosimus and Zonaras claim that their epigrams were inscribed on Julian's tomb in Tarsus while Kedrenos on the tomb in Constantinople. It is hard to conclude with complete certainty which epigram was engraved in which city, considering that there is no epitaph on the sarcophagus in Constantinople. Alexander Vasiliev suggests that:

- The writing was engraved not on the sarcophagus but on a stone or plaque attached to it.

- The sarcophagus from Tarsus is not the same as the one in Constantinople, hence, it bears no inscription. It means that Kedrenos fails to mention that detail in his story, which is likely.

- The sarcophagus in Constantinople is not where Julian is buried ${ }^{32}$.

${ }^{26}$ Zosimos, III, 34, 4.

${ }^{27}$ Zonaras, XIII, 13. 24.

${ }^{28}$ Anthologia graeca, VII, 747, ed. Н. BЕскву, München 1958.

${ }^{29}$ Homer, Iliada, III, 179, ed. J. Łanowski, trans. K. JeŻEWSKA, Wrocław 1981.

${ }^{30}$ Zosimos, III, 34, 4.

${ }^{31}$ Georgorius Cedrenus, Historiarum Compendium, I, 308, ed. I. BeKker, Bonnae 1838 [= CSHB] (cetera: Georgorius Cedrenus).

${ }^{32}$ A.A. VAsiliev, Imperial..., p. 8-9, 19-20. 


\section{Julian's tomb in Constantinople}

One of the porphyry sarcophagi preserved in The Istanbul Archeology Museum is believed by some to be the tomb of the emperor Julian the Apostate.

As mentioned by John Zonaras ${ }^{33}$, the body of the emperor Julian the Apostate was transferred from Tarsus to Constantinople. Most contemporary researchers assume that after his first burial in the suburb of Tarsus in Cilicia in 363, the emperor Julian was buried again at an unspecified time in the Church of the Holy Apostles in Constantinople $e^{34}$. This was also the resting place of his uncle, Constantine the Great. Unfortunately, the temple has not survived to the present time as it was destroyed by the Turks in 1461 .

The following Byzantine sources mention the tomb of the emperor Julian the Apostate in Constantinople:

1) In the collection De Ceremoniis aulae byzantinae ${ }^{35}$, Constantine VII Porphyrogennetos (the $10^{\text {th }}$ century) writes:

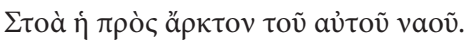

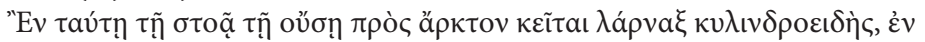

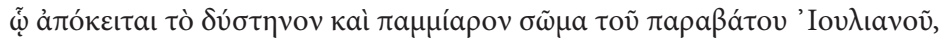

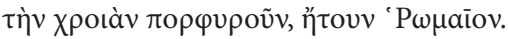

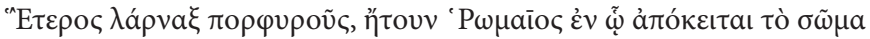

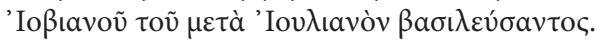

The Stoa to the North of the Same Church In this stoa, which is to the north, lies a cylindrically-shaped sarcophagus, in which lies the cursed and wretched body of the apostate Julian, porphyry or Roman in color.

Another sarcophagus, porphyry, or Roman, in which lies the body of Jovian, who ruled after Julian. ${ }^{36}$

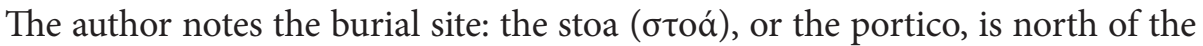
Church of the Holy Apostles. It is unclear whether it was a standalone building or a structure adjacent to the church. The researchers do not agree on that. Glanville Downey thinks that the northern and southern stoas were two separate buildings, independent of the main body of the church but within the churchyard ${ }^{37}$. Philip Grierson, on the other hand, claims that the northern stoa was the side chapel

\footnotetext{
${ }^{33}$ ZONARAS, XIII, 13.23-24.

${ }^{34}$ P. Grierson, C. Mango, I. Ševčenko, The Tombs and Obits..., p. 40-41; G. Downey, The Tombs..., p. 47; M. Di Maio, The Transfer..., p. 43-50; M.J. Johnson, Observations..., p. 259.

${ }^{35}$ Constantinus Porphyrogenitus, De Ceremoniis aulae byzantinae, II, 42, rec. J.J. Reiske, Bonnae 1829 [= CSHB, 5]; G. Downey, The Tombs..., p. 31-32; D. Woods, On the Alleged..., p. 365.

${ }^{36}$ G. Downey, The Tombs..., p. 34.

${ }^{37}$ Ibidem, p. 45-46.
} 
of that church while the southern stoa was a separate building ${ }^{38}$. Constantine Porphyrogennetos both describes the appearance of the sarcophagus, highlighting its porphyry color and cylindrical shape, and communicates his attitude

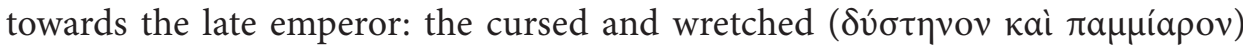

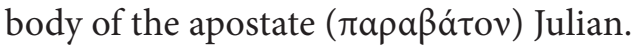

2) In Historiarum Compendium, George Kedrenos (the $11^{\text {th }}$ century) states ${ }^{39}$ :

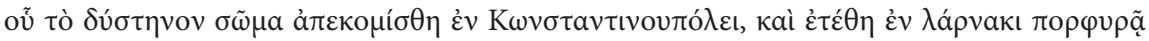

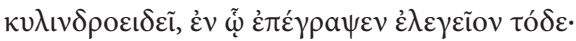

His wretched body was transferred to Constantinople and laid in a cylindrical, porphyry sarcophagus, on which the following poem was inscribed:

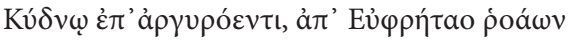

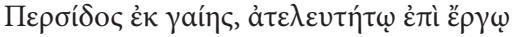

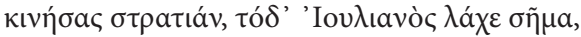

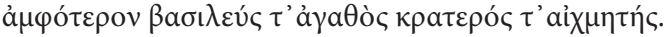

By the silver Cydnus, near the waters of the Euphrates,

In the country of Persia, having led the army but unable to complete his work

Julian, a famous emperor and a mighty warrior, was given this tomb. ${ }^{40}$

3) In his Chronicle John Zonaras (the $12^{\text {th }}$ century) writes ${ }^{41}$ :

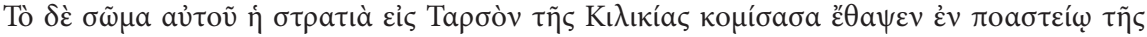

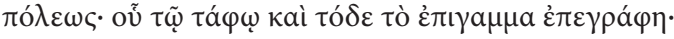

The army conveyed his body to Tarsus and buried it in a suburb of the city. On his grave was inscribed this epigram.

The text of the epigram is identical to the one in Kedrenos' text. Zonaras adds:

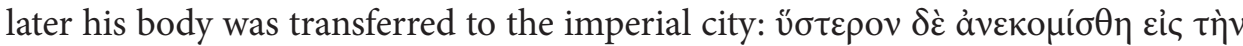
$\beta a \sigma ı \lambda i ́ \delta a \tau \tilde{\omega} v \pi o ́ \lambda \varepsilon \omega v$.

\footnotetext{
${ }^{38}$ P. Grierson, C. Mango, I. ŠEvčenko, The Tombs and Obits..., p. 36-38.

${ }^{39}$ Georgorius Cedrenus, I, 308.

${ }^{40}$ Translated by Katarzyna Szuster-Tardi, based on the Polish translation from the Greek by the author.

${ }^{41}$ Zonaras, XIII, 13.23-24; trans. - The History of Zonaras. From Alexander Severus to the Death of Theodosius the Great, trans. T. BANCHICH, E. LANE, preaf. T.M. BANCHICH, London 2009 [= Routledge Classical Translations], p. 176.
} 
Both Constantine Porphyrogennetos ( $\kappa \nu \lambda เ v \delta \rho o \varepsilon ı \delta \eta ́ \varsigma)$ and Kedrenos ( $\dot{\varepsilon} v \lambda a ́ \rho-$

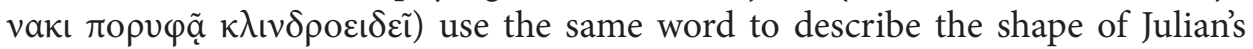
sarcophagus in Constantinople. On the sarcophagus that has been preserved until today, there is no inscription or even traces of it.

\section{The date and reason for moving Julian's sarcophagus to Constantinople}

Most contemporary researchers suspect that moving the tomb of the emperor Julian the Apostate occurred between the $4^{\text {th }}$ and the $10^{\text {th }}$ centuries $^{42}$. It is difficult to determine a specific date. Most likely, the ruler's remains have been located in Constantinople since the year 959, which is mentioned by Constantine Porphyrogennetos. The second burial most probably did not take place prior to 379 because Libanius only recalls a failed attempt at this project undertaken by the emperors Valens and Valentinian ${ }^{43}$.

If the transfer had taken place before 379, when Oration 24 was written, Libanius, a zealous supporter of Julian, would have likely mentioned it. Most probably, Julian's body remained in Tarsus between 389-390 because Ammianus Marcellinus makes no mention of it in his The Roman History. Neither Philostorgius, who completed Church History in 433 nor Zosimus, who wrote New History in the late $5^{\text {th }}$ century, speak of it. Both historians only mention Julian's burial in Tarsus but they fail to provide information about the second burial in Constantinople. This suggests that Julian's remains had not arrived in Constantinople before the early $6^{\text {th }}$ century but they did so no later than 959, when Constantine Porphyrogennetos' work was created. These, however, are no more than conjectures. It should be noted that Philostorgius' text is incomplete while Zosimus, who was Pagan, was not interested in disseminating information about Julian's burial in the Church of the Holy Apostles.

The question remains: Why were Julian's remains transferred to Constantinople? Perhaps it was a result of some important event in Tarsus? To ensure that Julian's body was not intercepted by the enemy? For instance, the remains of St. Augustine were presumably moved from Hippo to Sardinia to protect them from desecration during the raids of the Vandals. Michael Di Maio suggests that the reason for that were the battles waged in the $7^{\text {th }}$ century in Lesser Asia ${ }^{44}$. These might have been the fights between the Byzantine emperor Heraclius and the Persians between 610-628. Moreover, in the $7^{\text {th }}$ century, Arabs took control of the South-East part of the Byzantine Lesser Asia, including the city of Tarsus. The transfer of the remains of St. Paul the Apostle and St. John Chrysostom to Constantinople was also riddled with obstacles. Due to his anti-Christian politics, the emperor

\footnotetext{
${ }^{42}$ Cf. footnote 34 .

${ }^{43}$ Libanius, Orationes, XXIV, 1-11.

${ }^{44}$ M. Di Maio, The Transfer..., p. 46-47.
} 
Julian the Apostate was not popular among Christians. It is therefore unlikely that the immediate Christian successors were in any hurry to bring the Pagan's remains to Constantinople and bury them in the yard of the Church of the Holy Apostles. Such a decision would have outraged the Christians, who had been ill-treated by the dead emperor. Whoever was responsible for this transfer displayed a great deal of sensitivity choosing the location of the second burial - which was neither in the church proper nor the mausoleum but the northern stoa.

David Woods proposes an interesting hypothesis according to which Julian's remains have never been moved from Tarsus to Constantinople. The researcher doubts that Julian's tomb is located in the Church of the Holy Apostles. He thinks that the bishops and dwellers of Constantinople would not have allowed for such a man as Julian to be buried there, whether it was in the church proper or the churchyard. They unanimously condemned Julian. Moreover, the fact that none of his imperial successors were his descendants nor were they related to him may have contributed to the lack of the emperors' motivation to bury Julian in the Church of the Holy Apostles ${ }^{45}$.

It is likely that the transfer of Julian's remains to Constantinople would have indeed been opposed by the bishop, clergy, and populace. However, the opinion of these people on that matter was in reality of no great significance. The real issue is not whether they would have agreed to the burial of the Apostate at the complex of the Church of the Holy Apostles but how to determine who had the right to decide where an emperor could and could not be buried. The sources offer some indication about who had the final say regarding the imperial interment site. Only a ruling emperor could make such a decision. In 358, the Church of the Holy Apostles, where Constantine's remains were buried, was destroyed as a result of an earthquake. The bishop of Constantinople, Macedonius, gave an order to move the sarcophagus containing the imperial remains to the Church of St. Acacius. During the transfer, riots broke out in the city, probably because some of the dwellers believed that the removal violated the sanctity of the imperial burial and disgraced the memory of Constantine. The riots resulted in the deaths of several people. When the emperor Constantius II (337-361), the son of Constantine, learned about the transfer and riots, he was appalled ${ }^{46}$. Under no circumstances was the bishop authorized to move the sarcophagus with the body of Constantine. Hence, the choice of the location for the imperial burial belonged to the ruling emperor, and not the church officials, at least in the $4^{\text {th }}$ century.

It is a misconception to think that imperial burials which took place in the Church of the Holy Apostles in the $4^{\text {th }}$ century were in any way regulated by the church laws, simply because in that period, there was no general church politics regulating burials. This means that neither in the Roman law nor canonical

\footnotetext{
${ }^{45}$ D. Woods, On the Alleged..., p. 364-371.

${ }^{46}$ Socrates Scholasticus, II, 38; Sozomenus, IV, 21; Zonaras, XIII, 11.
} 
law was there any legal obstacle or prohibition preventing Pagans and Christians from being interred in the same place ${ }^{47}$. Therefore, there was no legal obstacle that could hinder the transfer of Julian's remains to the Church of the Holy Apostles. Moreover, Julian, as an emperor and heir to Constantine and Constantius had the right to be buried in an imperial mausoleum.

David Woods argues that the alleged transfer of Julian's remains was not included in the sources of the $4^{\text {th }}, 5^{\text {th }}$ and $6^{\text {th }}$ centuries ${ }^{48}$. He thinks that if such an important event had taken place, it would have surely been recorded by historians. It must be pointed out, however, that the information about imperial burials is not complete, e.g. the resting place of Constantine's father, Constantius Chlorus, who was adored by his military and received honorary obsequies and interment, was not recorded in any source. There is also no information about the burial site of other emperors, e.g. Gracian (367-383), Valentinian II (375-392), and a number of others. The remains of Vespasian (69-79) and Titus (79-81) were transferred by the emperor Domitian from the Mausoleum of Augustus to the Templum Gentis Flaviae but none of the authors at the time mentioned anything about the transfer nor about its circumstances. The fact that sources omit certain events does not mean that they did not happen. Furthermore, a great deal of sources has not been preserved till the present day.

In the $10^{\text {th }}$ century, imperial graves linked to the Church of the Holy Apostles were distributed among four different structures: the mausoleum of Constantine I, the mausoleum of Justinian I, the stoa south of the church, and the stoa north of the church. Probably, the fact that there were only two tombs in the north stoa - the alleged tomb of Julian an emperor Jovian - helped identify Julian's grave. One can suppose that the tombs of subsequent caesars would be close to one another. Hence, the location of Jovian's tomb in the stoa immediately suggested that the other tomb belonged to an emperor who ruled in the same period, that is, Julian. Naturally, there is no evidence to support this hypothesis. Perhaps the northern stoa was built specially to hold Jovian's tomb or, on the contrary, it had been built earlier. After Jovian's death, the mausoleum of Constantine I contained only two graves: of Constantine I, from the east side, and of Constantine II, from the north side. Hence, there was still a good share of space in the mausoleum, especially in its southern part. The mausoleum does not seem to have a clearly "familial" character. After several members of Constantine's dynasty were interred in Rome, the mausoleum soon adopted an imperial character, and not purely dynastic, thus becoming a model of the interment of emperors who were not related. The only reasonable explanation for the lack of Jovian's tomb in the mausoleum of Constantine was the fact that the northern stoa had already existed. Therefore, the subsequent emperors Valentinian I (364-375) and Valens (364-378) could decide where to

\footnotetext{
${ }^{47}$ M.J. Johnson, Observations..., p. 257-258.

${ }^{48}$ D. Woods, On the Alleged..., p. 366.
} 
bury Jovian. The grave of Jovian, whose rule was short and unremarkable, was as a result located in the northern stoa, and not in the mausoleum.

David Woods claims that the tomb identified in the Byzantine sources as emperor Julian the Apostate's, in reality, belonged to Crispus (Flavius Iulius Crispus, 317-326), the oldest son to Constantine the Great. The writers, who had a poor command of Latin, misread the inscription on the tomb. The evidence supporting this hypothesis is the full name of Crispus - Flavius Julius Crispus - which was probably shortened to Fl. Iul. Crispus. The Byzantine historians rarely recorded the full names of the rulers. Hence, the dwellers of Constantinople in the $10^{\text {th }}$ century only knew Crispus by this name, if they heard of him at all. They probably only knew Julian by this one name, too, and not in its entirety - Flavius Claudius Iulianus.

David Woods also believes that Constantine, having killed his first-born son, decided to move his remains to Constantinople and inter them in a small mausoleum - in the northern stoa. Did Constantine intend to bury Crispus in the Church of the Holy Apostles and why would he transfer his remains to Constantinople if other members of his family had been buried in various other places? His mother Helena, his daughters Constantina and Helena, the wife of Julian the Apostate, were buried in Rome while his son Constans was probably laid to rest in the mausoleum in Centcelles in Spain. Why were this transfer and interment not mentioned by any of the authors, even though they do comment on the circumstances surrounding the death of Crispus? It thus seems unlikely that this was the tomb of Crispus ${ }^{49}$.

\section{Recapitulation}

Based on the sources, it can be concluded that the body of the emperor Julian the Apostate was beyond a doubt escorted by Procopius and a section of the soldiers from the place of his death to Tarsus in Cilicia because this was where he had intended to stay upon completing his Persian campaign.

The tomb of the emperor is located in the suburb of Tarsus by the road leading to the passes of Mount Taurus, in a mausoleum next to a small temple on the bank of the River Cydnus. An inscription was engraved on the sarcophagus, which is confirmed by Zosimus and Zonaras. It was written by someone close to the dead emperor, perhaps his friend, the physician Oribasius.

The Byzantine historians Constantine VII Porphyrogennetos, George Kedrenos, and John Zonaras recall the transfer of the emperor's remains to the Church of the Holy Apostles in Constantinople. They unanimously agree that the tomb of the emperor Julian the Apostate was a porphyry, cylindrically-shaped sarcophagus in the northern stoa. None of the sources mention, however, who performed this

${ }^{49}$ Ibidem, p. 369-371. 
transfer and when nor why they thought it was necessary. Kedrenos notes that there was an inscription on Julian's sarcophagus in Constantinople. The one which has survived until today does not have an inscription nor any traces of it - perhaps it was not permanently affixed to the tomb. This may also suggest that there were two sarcophagi of Julian's: one from Tarsus, which has not been preserved, with an engraved epitaph; and the second from Constantinople - porphyry, cylindrical with no inscription.

The tomb of the emperor Julian the Apostate was transferred between the $4^{\text {th }}$ and $10^{\text {th }}$ centuries. It is difficult to determine the specific date because there are no direct sources. Perhaps the reason for the transfer was some important political event, e.g. battles with Persians or Arabs in the $7^{\text {th }}$ century and the subsequent fear of the destruction of the imperial remains.

The northern stoa, where Julian was supposedly buried, was most likely not built right after his death or his body was not promptly laid there. It may be that Julian, due to his apostasy, could not be interred along with the other members of his dynasty. Nevertheless, while his apostasy may have caused a certain delay in the transfer of his body, he was a Roman emperor and this sufficed to bury him in Constantinople. The laws regulating burials in the $4^{\text {th }}$ century would have allowed for the interment of Julian in the complex of the Church of the Holy Apostles. While it cannot be concluded with complete certainty that Julian's remains were indeed transferred to the capital, it should be noted that this was a possibility. The alleged transfer of Julian's remains to the Church of the Holy Apostles could have happened although the sources at that time make no mention of it. Moreover, in the $4^{\text {th }}$ century, neither the Roman nor the canonical law offered any legal grounds preventing his second burial from taking place in the complex of the Church of the Holy Apostles. On the whole, insufficient source material makes it impossible to unambiguously determine what became of the remains of the emperor Julian the Apostate. 


\section{Bibliography}

\section{Primary Sources}

Ammianus Marcellinus, vol. I-III, trans. J.C. Rolfe, London 1950-1952 [= Loeb Classical Library, 300]. Anthologia graeca, ed. Н. Вескву, München 1958.

Constantinus Porphyrogenitus, De Ceremoniis aulae byzantinae, rec. J.J. Reiske, Bonnae 1829 [= Corpus scriptorum historiae byzantinae, 5].

Eutropii Breviarium ab Urbe condita, ed. C. SAntini, Leipzig 1979.

Georgorius Cedrenus, Historiarum Compendium, ed. I. Bekker, Bonnae 1838 [= Corpus scriptorum historiae byzantinae].

Gregorius Nazianensis, Oratio, V, [in:] Patrologiae cursus completus, Series graeca, vol. XXXV, ed. J.-P. Migne, Paris 1857, col. 664-720.

The History of Zonaras. From Alexander Severus to the Death of Theodosius the Great, trans. T. BAN$\mathrm{CHICH}$, E. LANE, preaf. T.M. BANCHICH, London 2009 [= Routledge Classical Translations].

Homer, Iliada, ed. J. Łanowski, trans. K. JeżewsKa, Wrocław 1981.

Ioannis Zonarae Epitome historiarum libri XIII-XVIII, rec. T. BÜTTNER-WoBst, Bonnae 1897.

\section{Julian the Apostate}

Cesarz Juljan Apostata i jego satyra Symposion, trans. L. ĆwıkLIŃski, Poznań 1936.

Julian Apostata, Cesarze, trans. A. Pająkowska, Poznań 2013 [= Fontes Historiae Antiquae. Zeszyty Źródłowe Zakładu Historii Społeczeństw Antycznych, 27].

Julian Apostata, Listy, trans. W. Klinger, Wrocław 1962 [= Biblioteka Przekładów z Literatury Antycznej, 9].

Julian Apostata, List do filozofa Temistiosa, trans. A. Pająkowska, Poznań 2011 [= Fontes Historiae Antiquae. Zeszyty Źródłowe Zakładu Historii Społeczeństw Antycznych, 22].

Julian Apostata, List do rady i ludu ateńskiego, trans. A. PająKowska, Poznań 2006 [= Fontes Historiae Antiquae. Zeszyty Źródłowe Zakładu Historii Społeczeństw Antycznych, 7].

Julian Apostata, Misopogon, czyli Nieprzyjaciel brody, trans. A. PająKowska, Poznań 2009 [= Fontes Historiae Antiquae. Zeszyty Źródłowe Zakładu Historii Społeczeństw Antycznych, 13].

Julian Apostata, Przeciw Galilejczykom, trans. A. Pająkowska, Poznań 2012 [= Fontes Historiae Antiquae. Zeszyty Źródłowe Zakładu Historii Społeczeństw Antycznych, 24].

The Works of the Emperor Julian, vol. I-III, trans. W.C. WRIGHT, London-Cambridge Mass. 1962-1969 [= Loeb Classical Library, 13; 29; 157].

$$
* * *
$$

Libanius, Selected Works, vol. I, The Julianic Orations, ed. et trans. A.F. Norman, London-Cambridge Mass. 1987 [= Loeb Classical Library, 451].

Philostorgius, Kirchengeschichte, ed. J. Bidez, F. Winkelmann, Berlin 1981 [= Die griechischen christlichen Schriftsteller der ersten [drei] Jahrhunderte].

SoKrates, Kirchengeschichte, ed. G.C. HANSEn, Berlin 1995 [= Die griechischen christlichen Schriftsteller der ersten [drei] Jahrhunderte. Neue Folge, 1]. 
Sozomenus, Kirchengeschichte, ed. J. Bidez, G.C. Hansen, Berlin 1995 [= Die griechischen christlichen Schriftsteller der ersten [drei] Jahrhunderte. Neue Folge, 4].

The Theodosian Code and Novels and the Sirmondian Constitutions, trans. et ed. C. PHARR, praef. C. Dickerman Williams, Princeton 1952.

Zosime, Histoire nouvelle, ed. et trans. F. Paschoud, vol. I-III, Paris 1979-2000.

Zosimus, New History, trans. R.T. Ridley, Canberra 1982 [= Byzantina Australiensia, 2].

\section{Secondary Literature}

Arce J., La tumba del Emperador Juliano, "Lucentum. Anales de la Universidad de Alicante. Prehistoria, Arqueología e Historia Antigua" 3, 1984, p. 181-191.

Athanassiadi P., Giuliano. Ultimo degli imperatori pagani, Genova 1994.

Athanassiadi P., Julian. An Intellectual Biography, London-New York 1992.

BIDEZ J., La vie de l'Empereur Julien, Paris 1930.

Bielas L., Apostazja cesarza Juliana w świadectwach antycznych pisarzy i w nowożytnej historiografii, Kraków 2002.

Bowersock G.W., Julian the Apostate, London 1978.

Braun R., Richer J., L'empereur Julien. De l'histoire à la légende, Paris 1978.

Bringmann K., Kaiser Julian. Der letzte heidnische Herrscher, Darmstadt 2004.

Browning R., The Emperor Julian, Los Angeles 1978.

CERAN W., Kościół wobec antychrześcijańskiej polityki cesarza Juliana Apostaty, Łódź 1980 (= "Acta Universitatis Lodziensis. Folia Historica" 1).

Conduché D., Ammien Marcellin et la mort de Julien, "Latomus" 24, 1965, p. 359-380.

Downey G., The Tombs of the Byzantine Emperors at the Church of the Holy Apostles in Constantinople, "Journal of Hellenic Studies" 79, 1959, p. 27-51.

DrabiK A., Ktezyfont 363, Warszawa 2016.

Farrokh K., Maksymiuk K., Gracia J.S., The Siege of Amida (359 CE), Siedlce 2018.

Fornara C.W., Julian's Persian Expedition in Ammianus and Zosimus, "Journal of Hellenic Studies" 111, 1991, p. 1-15.

Grierson P., Mango C., ŠevčEnko I., The Tombs and Obits of the Byzantine Emperors (337-1042), "Dumbarton Oaks Papers" 16, 1962, p. 1-63.

Hahn I., Der ideologische Kampf um den Tod Julians des Abtrünnigen, "Klio. Beiträge zur alten Geschichte" 38, 1960, p. 225-232.

Harrel J.S., Wojna o Nisibis. Obrona rzymskiej wschodniej granicy 337-363, trans. A. PARAdzIŃski, Oświęcim 2019.

JaCzynowska M., Imitatio Alexandri. Parę uwag na temat perskiej wyprawy cesarza Juliana, "Acta Universitatis Nicolai Copernici. Historia” 29, 1996, p. 133-148.

Jerphagnon L., Julien dit l'Apostat, Paris 2008.

Johnson M.J., Observations on the Burial of the Emperor Julian in Constantinople, "Byzantion. Revue internationale des études byzantines" 77, 2008, p. 254-260.

KuRAnC J., Zgon cesarza Juliana Apostaty w świetle relacji wspótczesnych pisarzy pogańskich, "Roczniki Humanistyczne" 14, 1966, p. 73-86. 
Maio M. Di, The Transfer of the Remains of the Emperor Julian from Tarsus to Constantinople, "Byzantion. Revue internationale des études byzantines" 48, 1978, p. 43-50.

Marcone A., Giuliano, Roma 2018.

Negri G., L’imperatore Giuliano Apostata, Milano 1901.

Olszaniec S., Julian Apostata jako reformator religijny, Kraków 1999.

PAJĄKowsKa A., Historyk Ammianus Marcellinus o śmierci cesarza Juliana Apostaty, "Studia Classica et Neolatina" 7, 2005, p. 9-21.

Ramos P., La veritable histoire de Julien, Paris 2012.

Ricciotti G., L'imperatore Giuliano l'Apostata secondo i documenti, Verona 1962.

Ridley R.T., Notes on Julian's Persian Expedition (363), "Historia. Zeitschrift für alte Geschichte" 22, 2, 1973, p. 317-330.

Rosen K., Julian. Kaiser, Gott und Christenhasser, Stuttgart 2006.

SińczaK T., Wojny Cesarstwa Rzymskiego z Iranem Sasanidów w latach 226-363, Oświęcim 2016.

Sмith R., Julian's Gods. Religion and Philosophy in the Thought and Action of Apostate, London-New York 1995.

SPInelli M., Giuliano l'Apostata. Anticristo o cercatore di dio?, Roma 2017.

Szeląg T., Amida 359, Warszawa 2012.

SzeląG T., Kampanie galijskie Juliana Apostaty. Argentoratum 357, Zabrze 2007.

Teitler H.C., The Last Pagan Emperor. Julian the Apostate and the War against Christianity, Oxford 2017.

Vasiliev A.A., Imperial Porphyry Sarcophagi in Constantinople, "Dumbarton Oaks Papers" 4, 1948, p. 1-26.

Wolski J., Julian Apostata. Życie i twórczość, [in:] Julian Apostata, Listy, trans. W. Kuinger, Wrocław 1962 [= Biblioteka Przekładów z Literatury Antycznej, 9], p. V-XVII.

Woods D., Gregory of Nazianzus on the Death of Julian the Apostate (Or. 5.13), "Mnemosyne: a Journal of Classical Studies" 68, 2015, p. 297-303.

Woods D., On the Alleged Reburial of Julian the Apostate in Constantinople, "Byzantion. Revue internationale des études byzantines" 76, 2006, p. 364-371.

\footnotetext{
Abstract. Julian (Flavius Claudius Iulianus), called the Apostate, Roman emperor in the years 361-363, was one of the most intriguing rulers. From antiquity to the present day he invariably aroused great interest, both during his life and after his death. He was a just emperor, a wise commander, and a very talented writer.

On 26 June 363 Julian the Apostate was mortally wounded during a battle with the Persians. He spent the last moments of his life discussing with philosophers Priskus and Maksimus the nobility of the soul, as we learn from the historian Ammianus Marcellinus. The ruler then showed, perhaps too ostentatiously, his greatest passion: love of virtue and fame.

Julian the Apostate died at the age of thirty-two after only twenty months of his rule. Julian's body, as Gregory of Nazianzus recalls, was transported from Nisibis to Tarsus in Cilicia, which took fifteen days. The subjects greeted the arrival of the body with a mournful lament or contemptuous insults, as the Father of the Church adds. Julian wanted to rest after death in Tarsus, in a mausoleum next to a small temple on the banks of the Cydnus River.
} 
Then, at an unspecified time, as the chronicler Zonaras recalls, the body of Emperor Julian the Apostate was transferred to Constantinople and buried in the Church of the Holy Apostles. Constantine Porphyrogenitus in his collection On the ceremonies of the imperial court (book II, chapter 42) mentions the grave of Julian. Today one of the porphyry sarcophagi, kept in the Archaeological Museum in Istanbul, is sometimes considered the Julian sarcophagus.

The theme of this article is an attempt to determine the posthumous fate of Emperor Julian the Apostate's body, i.e. when and in what circumstances it was transferred to Constantinople.

Keywords: Julian the Apostate, Roman Empire in the $4^{\text {th }}$ century AD, imperial burial, Church of the Holy Apostles in Constantinople.

Anna Pająkowska-Bouallegui

University of Gdansk

Faculty of Languages

Department of Classical Philology

ul. Wita Stwosza 55

80-308 Gdańsk, Poland

a.pajakowska-bouallegui@ug.edu.pl 